\title{
KEPASTIAN HUKUM ATAS SUATU KEPEMILIKAN OBJEK JAMINAN FIDUSIA YANG TELAH DINYATAKAN DIRAMPAS OLEH NEGARA BERDASARKAN PUTUSAN PENGADILAN
}

\section{Aneta Indriya Sari, Gunawan Djajaputra}

Universitas Tarumanegara (UNTAR) Jakarta, Indonesia

Email: aindrya@hotmail.com,gunawand@fh.untar.ac.id

\begin{abstract}
Abstrak
Dilatarbelakangi oleh adanya perampasan objek jaminan fidusia oleh negara sebagai akibat dari tindak pidana yang telah dilakukan debitur selaku pemberi fidusia, sehingga merugikan kreditur sebagai penerima fidusia, maka dibuatlah oleh penulis tesis yang berjudul: "Kepastian Hukum Atas Suatu Kepemilikan Objek Jaminan Fidusia Yang Telah Dinyatakan Dirampas Oleh Negara Berdasarkan Putusan Pengadilan" (Studi Putusan Pengadilan Tinggi Bandung Nomor 476/Pdt/2020/Pt. Bdg Tanggal 30 September 2020), yang bertujuan untuk meneliti apakah status kepemilikan objek jaminan fidusia akan menjadi hilang dengan telah dinyatakannya "dirampas oleh negara" berdasarkan suatu putusan pengadilan, serta menganalisis bagaimana kepastian hukumnya. Metode penelitian yang digunakan adalah yuridis normatif dengan menggunakan pendekatan deskriptif analitis yang bersumber dari beberapa bahan hukum khususnya primer dan sekunder maupun tersier untuk melakukan suatu analisis melalui berbagai peraturan perundangundangan serta suatu putusan pengadilan, dimana telah terjadi kekosongan norma yang disebabkan karena belum adanya suatu peraturan mengenai objek jaminan fidusia yang dirampas negara serta akibat hukum dari perampasan benda tersebut. Sudah sepatutnya objek jaminan fidusia yang merupakan suatu objek jaminan yang sah, yang telah disita, dikembalikan kepada pemiliknya yang sah yang dalam hal ini adalah Kreditur.
\end{abstract}

Kata Kunci: jaminan fidusia; kepemilikan objek jaminan fidusia; perampasan negara

\section{Abstract}

Against the background of the seizure of the object of fiduciary security by the state as a result of criminal acts that have been committed by the debtor as the fiduciary giver, thus harming the creditor as the recipient of the fiduciary, then the author of the thesis entitled: "Legal Certainty on a Ownership of Fiduciary Guarantee Objects That Have Been Declared Seized By The State Based On Court Decisions", (Case Study of Bandung High Court Decision Number 476/Pdt/2020/Pt. Bdg dated 30 September 2020), which aims to examine whether the ownership status of the fiduciary guarantee object will be lost by it has been declared "confiscated by the state" based on a court decision, as well as analyze how the legal certainty is. The research method used is normative juridical using a descriptive analytical approach sourced from several legal materials, especially primary and secondary

$\begin{array}{ll}\text { How to cite: } & \text { Sari, Aneta Indriya., Gunawan Djajaputra (2021) Kepastian Hukum Atas Suatunkepemilikan Objek } \\ & \text { Jaminan Fidusia Yang Telah Dinyatakan Dirampas Oleh Negara Berdasarkan Putusan Pengadilan. } \\ & \text { Syntax Literate: Jurnal Ilmiah Indonesia. 6(7). http://dx.doi.org/10.36418/syntax-literate.v6i7.3487 } \\ \text { E-ISSN: } & 2548-1398 \\ \text { Published by: } & \text { Ridwan Institute }\end{array}$


and tertiary to conduct an analysis through various laws and regulations as well as a court decision, where there has been a void of norms caused by the absence of a regulation regarding the object of fiduciary security seized by the state and the legal consequences of the confiscation of the object. It is proper that the object of fiduciary security which is an object of legal security, which has been confiscated, should be returned to its rightful owner, which in this case is the Creditor.

Keywords: fiduciary security; ownership of fiduciary guarantee objects; state confiscation

\section{Pendahuluan}

Indonesia termasuk salah satu negara yang perkembangan perekonomiannya cukup pesat. Guna menunjang pertumbuhan perekonomian yang pesat tersebut diperlukan dana yang cukup besar (Jenie, 1996). Untuk itu sarana penyediaan dana yang dibutuhkan masyarakat perlu diperluas. Dalam rangka pembangunan dibidang ekonomi, maka diperlukan tersedianya dana yang salah satunya adalah dalam bentuk kredit yang diberikan oleh lembaga perbankan (Darmaji, 2006).

Pemberian kredit yang didapatkan dari sumber pendanaan yang berasal dari bank tersebut tidak serta merta tidak mengandung resiko dalam pelaksanaannya. Kreditur dan debitur harus membuat suatu perjanjian dimana kedua belah pihak dapat saling mengikat. Perjanjian tersebut tentu memerlukan jaminan. Karena pihak Bank membutuhkan kepastian untuk pengembalian pinjaman yang diberikan kepada debitur atau nasabahnya (Purnamasari, 2012).

Bila dicermati keberadaan lembaga perbankan tidak mencukupi kebutuhan akan dana tersebut. Oleh karena itu diperlukan adanya alternatif pembiayaan lainnya selain bank (non-bank). Adanya alternatif pembiayaan lainnya dimaksud dibutuhkan mengingat akses untuk mendapatkan dana dari bank sangat terbatas.

Mengantisipasi hal tersebut, maka pemerintah pada tahun 1988 melalui Keputusan Presiden No. 61 Tahun 1988 tentang Lembaga Pembiayaan, membuka peluang bagi berbagai badan usaha untuk melakukan kegiatan-kegiatan pembiayaan sebagai alternatif lain untuk menyediakan dana guna menunjang pertumbuhan perekonomian Indonesia tersebut. Kegiatan-kegiatan pembiayaan tersebut dilakukan oleh suatu lembaga yang namanya "Lembaga Pembiayaan" (Finance Company) (Elfanto Jurdana, 2007).

Melalui lembaga pembiayaan dimaksud para pelaku usaha/bisnis bisa mendapatkan dana atau modal yang dibutuhkan. Keberadaan lembaga pembiayaan ini sangat penting, karena fungsinya hampir mirip sama dengan bank. Dalam prakteknya sekarang ini lembaga pembiayaan banyak dimanfaatkan oleh pelaku usaha/bisnis ketika membutuhkan dana atau barang modal untuk kepentingan perusahaan.

Perkembangan lembaga pembiayaan, khususnya pembiayaan konsumen memang belum ditopang oleh perangkat hukum yang memadai, sehingga karenanya diperlukan adanya perangkat hukum dalam bentuk undang-undang agar ada jaminan kepastian hukum terkait dengan operasional pembiayaan konsumen tersebut. Kepastian hukum 
dimaksud menjadi tuntutan para pelaku ekonomi dalam melakukan aktivitasnya dibidang ekonomi, termasuk di bidang kegiatan pembiayaan.

Sektor hukum memang harus dapat mengikuti perkembangan ekonomi yang sedang berlangsung. Selama ini kelemahan utama bidang hukum yang sering dihadapi oleh pelaku ekonomi di Indonesia adalah masalah ketidakpastian hukum. Padahal kepastian hukum juga dibutuhkan untuk memperhitungkan atau mengantisipasi resiko (Sulistiyono \& Rustamaji, 2009).

Pada prinsipnya dalam suatu perjanjian kredit/pembiayaan baik oleh bank maupun oleh perusahaan pembiayaan, yang pengikatan objek agunannya dilakukan melalui lembaga jaminan fidusia adalah dengan tujuan mengamankan aset bank/perusahaan yang diberikan kepada debitur melalui suatu perjanjian kredit/perjanjian pembiayaan dari resiko debitur tidak mampu mengembalikan hutang-hutangnya kepada pihak bank atau perusahaan pembiayaan tersebut. Dengan demikian dapat dikatakan pengikatan objek agunan dengan menggunakan lembaga jaminan fidusia merupakan suatu perjanjian accesoir, dimana perjanjian kredit/perjanjian pembiayaan yang terlebih dahulu dilaksanakan sebagai perjanjian pokoknya (Gunawan Widjaja \& Ahmad Yani, 2000).

Perjanjian pembiayaan konsumen pada perusahaan pembiayaan merupakan perjanjian hutang-piutang antara pihak perusahaan pembiayaan dengan konsumen. Berhubung karena pihak perusahaan pembiayaan telah membayar lunas harga barang yang dibutuhkan oleh konsumen tersebut kepada dealer/pemasok dan pihak perusahaan pembiayaan menyerahkan barang tersebut kepada konsumen/debitur berdasarkan atas kepercayaan bahwa konsumen tersebut akan membayar secara angsuran/ berkala harga barang tersebut hingga lunas sesuai besar angsuran dan jangka waktu angsuran sebagaimana yang telah ditetapkan melalui kesepakatan diantara pihak perusahaan pembiayaan maupun konsumen (Darwanto, 2006).

Dalam suatu perjanjian pembiayaan konsumen yang objek jaminannya berupa kendaraan bermotor khususnya mobil maka pihak perusahaan pembiayaan akan melaksanakan pengikatan objek jaminan fidusia terhadap mobil yang telah diserahkan kepada konsumen tersebut. Tujuan difidusiakannya mobil yang telah diserahkan kepada konsumen tersebut adalah untuk mendapatkan hak preferen (hak yang didahulukan) dari kreditur yang lain, serta mendapatkan hak eksekutorial atas objek jaminan tersebut sekaligus mengamankan kreditur atas perjanjian yang telah dibuatnya tersebut dari resiko macetnya angsuran atau dipindahtangankannya mobil yang telah diikat dengan jaminan fidusia tersebut. Dengan diikatnya objek jaminan fidusia yaitu mobil dalam suatu perjanjian pengikatan jaminan fidusia dalam pelaksanaan pembiayaan tersebut dan mendaftarkannya ke Kantor Pendaftaran Fidusia di wilayah Departemen Hukum dan Hak Asasi Manusia, maka apabila terjadi resiko konsumen tidak mampu melunasi angsuran atau konsumen memindahtangankan barang (mobil) yang telah menjadi objek jaminan fidusia tersebut, perusahaan pembiayaan sebagai pihak kreditur dapat mengeksekusi barang (mobil) tersebut karena masih menjadi hak kepemilikannya (Djasman, 2009). 
Suatu perjanjian kredit atau pembiayaan yang melibatkan kreditur sebagai pemberi pinjaman atau penyedia dana dan debitur sebagai peminjam dana, memiliki hubungan serta kepentingan yang saling timbal balik. Landasan utama dalam pemberian pinjaman ataupun pembiayaan kepada debitur adalah kepercayaan.

Salah satu jaminan kebendaan berdasarkan kepercayaan adalah fidusia. Dalam Pasal 1 ayat (1) Undang-undang Nomor 42 Tahun 1999 tentang Jaminan Fidusia ("UUJF"), diatur definisi mengenai fidusia yaitu, "Fidusia adalah pengalihan hak kepemilikan suatu benda atas dasar kepercayaan dengan ketentuan bahwa benda yang hak kepemilikannya dialihkan tersebut tetap dalam penguasaan pemilik benda."

Berdasarkan definisi tersebut dapat diartikan bahwa terhadap objek jaminan fidusia apabila kepemilikan dan hak atas benda dialihkan kepada penerima fidusia atas dasar kepercayaan, maka benda jaminan tersebut masih berada pada penguasaan penerima fidusia.

Di era kini banyak debitur yang curang karena menggadaikan objek jaminan fidusia pada pihak ketiga. Tidak sedikit pula kreditur yang menggunakan objek jaminan tersebut untuk melakukan tindak kejahatan atau tindak pidana. Akibat perbuatan tersebut debitur akan menerima sanksi sesuai dengan perjanjian fidusia yang telah disepakati bersama atau sesuai dengan hukum yang berlaku. Objek jaminan pun dapat disita oleh Negara jika debitur menggunakan objek jaminan untuk melakukan perbuatan melawan hukum. Hak preferen (didahulukan/diutamakan) yang dimiliki oleh penerima fidusia sebagaimana dimaksud menjadi tidak bermakna manakala benda yang dijadikan jaminan fidusia itu tidak lagi berada dalam kekuasaan debitur, karena benda tersebut dirampas untuk negara akibat tindak pidana yang dilakukan debitur terkait kasus penghimpunan dana secara ilegal dari masyarakat, seperti kasus yang menimpa PT Mizuho Balimor Finance, sebagai salah satu perusahan pembiayaan di Indonesia.

Penguasaan objek jaminan fidusia dalam UUJF yang tetap pada pemberi fidusia selaku debitur, menyebabkan banyak kemungkinan bagi para debitur dalam mempergunakan objek jaminan fidusia untuk melakukan berbagai tindak pidana (kriminal) yang dapat menyebabkan objek jaminan fidusia menjadi dirampas oleh negara, contohnya tindak pidana ekonomi dan tindak pidana narkotika. Sekalipun dalam UUJF telah mengatur secara tegas mengenai kepemilikan atas objek jaminan fidusia, namun ironisnya dikalangan penegak hukum khususnya jaksa serta hakim, seolah dengan mudahnya mengabaikan keberadaan atas kepemilikan objek jaminan fidusia tersebut. Lemahnya kekuatan hukum daripada UUJF itu sendiri berdampak pula pada melemahnya perlindungan hukum bagi para penerima fidusia selaku kreditur yang disebabkan karna didalam UUJF itu sendiri tidak mengatur mengenai akibat hukum bagi benda dan kepemilikan jaminan Fidusia yang dirampas oleh negara, sehingga dalam hal ini terjadi norma kosong atau ketiadaan peraturan perundang-undangan.

Dengan ditetapkannya benda milik kreditur sebagai barang bukti atas suatu tindak pidana yang untuk kemudian ditetapkan menjadi dirampas oleh negara, juga telah merugikan hak eksekutorial kreditur selaku penerima fidusia dalam melaksanakan eksekusi jaminan fidusia atas benda miliknya sebagai akibat dari tertundanya 
pembayaran hutang atau pinjaman debitur kepada kreditur (cidera janji) yang disebabkan karena tindak pidana yang telah dilakukan oleh debitur itu sendiri.

Pasal 24 UUJF No. 42 Tahun 1999 menyebutkan bahwa, "Penerima fidusia tidak menanggung kewajiban atas akibat tindakan atau kelalaian fidusia baik yang timbul dari hubungan kontraktual atau yang timbul dari perbuatan melanggar hukum sehubungan dengan penggunaan dan pengalihan benda yang menjadi objek jaminan fidusia". Dari ketentuan Pasal 24 UUJF No. 42 Tahun 1999 tersebut di atas dapat dikatakan bahwa penerima fidusia tidak menanggung akibat atas perbuatan melanggar hukum dari pemberi fidusia terhadap objek jaminan fidusia tersebut. Apabila ternyata dikemudian hari objek jaminan fidusia yang diberikan oleh pemberi fidusia diperoleh dengan melanggar ketentuan hukum pidana maka penerima fidusia tidak ikut menanggung akibat apabila objek jaminan fidusia tersebut dirampas/ disita oleh negara. Begitu juga menyangkut risiko dari seluruh aktivitas pembiayaan konsumen yang memang tidak mungkin terhindar dari prihal resiko tersebut.

Pengertian dari dirampas untuk negara itu sendiri kemudian terdapat pada Peraturan Menteri Kehakiman Republik Indonesia Nomor M.05.UM.01.06 Tentang Pengelolaan Benda Sitaan Negara dan Barang Rampasan Negara yang artinya barang rampasan adalah barang bukti yang telah memproleh kekuatan hukum tetap, dirampas untuk negara yang selanjutnya dieksekusi dengan cara (R. Supomo, 2005):

1. Dimusnahkan;

2. Dilelang untuk negara;

3. Diserahkan kepada instansi yang ditetapkan untuk dimanfaatkan; dan

4. Diserahkan di Ruah Penyimpanan Benda Sitaan (RUPBASAN) untuk barang bukti dalam perkara lain.

Dalam penelitian ini PT Mizuho Balimor Finance sebagai perusahaan pembiayaan yang telah memberikan fasilitas pembiayaan kendaraan berupa mobil kepada konsumen (debitur) sekaligus merupakan penerima fidusia dalam Akta Jaminan Fidusia, dimana konsumen (debitur) bertindak sebagai pemberi fidusia maka perusahaan pembiayaan tersebut seharusnya tidak bertanggung jawab dan tidak ikut menanggung beban kerugian bila objek jaminan fidusia tersebut terkait dengan tindak pidana dan dirampas/ disita oleh Negara.

Kasus yang dibahas dalam penelitian ini adalah kasus tindak pidana perbankan (menghimpun dana masyarakat secara illegal) yang dilakukan oleh terpidana Tohiron yang menjadikan 1 (satu) unit mobil Honda Mobilio RS CVT warna putih metalik (white orchid pearl), Nomor Polisi B 154 NCA Nomor Rangka MHRDD4870FJ458418 Nomor Mesin L15Z11211115 atas nama Djohanah (istri terpidana/debitur) yang dinyatakan dirampas oleh negara. Dimana mobil tersebut adalah milik debitur Tohiron yang mengikatkan mobil tersebut sebagai jaminan fidusia pada PT Mizuho Balimor Finance dengan Akta Jaminan Fidusia No. 137 Tanggal 31 Desember 2015 yang dibuat dihadapan Notaris Natalia Pandiangan, Sarjana Hukum.

Penyitaan yang dilakukan oleh negara (pengadilan) disebabkan adanya dugaan tindak pidana pebankan terhadap 1 (satu) unit mobil Honda Mobilio RS CVT yang 
mana hasil dari tindak pidana tersebut digunakan oleh debitur Tohiron untuk membayar uang muka atas fasilitas pembiayaan yang telah diberikan oleh PT Mizuho Balimor Finance telah diikat melalui suatu perjanjian pembiayaan yang selanjutnya dituangkan ke dalam akta otentik, yaitu Akta Jaminan Fidusia.

Disamping itu, sekalipun kreditur telah memenuhi ketentuan terkait Mitigasi Risiko Pembiayaan berdasarkan peraturan OJK dimana Perusahaan Pembiayaan wajib melakukan mitigasi risiko pembiayaan, yang salah satunya dapat dilakukan dengan cara mengalihkan risiko atas agunan dari kegiatan pembiayaan melalui mekanisme asuransi, namun pengalihan resiko atas agunan melalui penutupan asuransi hanya sebatas pada peristiwa kehilangan (total loss only (TLO), dimana penutupan asuransi atas resiko peristiwa penyitaan dan perampasan oleh negara tidak dikenal dalam perasuransian. Dalam hal terjadinya penyitaan/perampasan oleh negara terhadap objek jaminan fidusia maka perusahaan asuransi tidak akan memberikan ganti rugi atas terjadinya peristiwa tersebut.

Pembahasan mengenai masalah objek dari pembiayaan konsumen yang disita oleh negara melalui suatu putusan pengadilan inilah yang menarik untuk dibahas lebih lanjut dalam pembahasan selanjutnya pada penulisan ini. Pembahasan difokuskan pada ketentuan perundang-undangan tentang pengikatan objek Jaminan Fidusia pada perusahaan pembiayaan, status hukum objek jaminan fidusia yang merupakan objek dari pembiayaan konsumen yang disita oleh negara melalui putusan pengadilan berkaitan dengan kasus tindak pidana perbankan dan bagaimana kepastian hukum atas kepemilikan objek jaminan fidusia yang telah dinyatakan dirampas oleh negara melalui putusan pengadilan yang berkaitan dengan kasus tindak pidana perbankan tersebut. Dalam hal terjadinya penyitaan/perampasan oleh negara terhadap objek jaminan fidusia maka perusahaan asuransi tidak akan memberikan ganti rugi atas terjadinya peristiwa tersebut.

\section{Metode Penelitian}

Adapun metode pendekatan yang digunakan dalam penulisan ini terutama adalah pendekatan yuridis normatif. Penulisan ini merupakan penulisan yuridis normatif tentang persoalan-persoalan yang menyangkut tentang sinkronisasi hukum kepemilikan atas objek jaminan fidusia dengan ketentuan-ketentuan yang berkaitan dengan penyitaan dan perampasan oleh negara.

Berdasarkan hal kajian yang dilakukan oleh penulis melalui penulisan yuridis normative, maka pendekatan yang dilakukan dalam penulisan ini adalah Pendekatan Kasus (Case Approach), Pendekatan Konseptual (Conseptual Approach) dan Pendekatan Perundang-Undangan (Statue Approach).

1. Pendekatan Kasus (Case Approach).

Dalam penelitian ini peneliti menggunakan pendeketan kualitatif dengan jenis penelitian case studyresearch (studi kasus) dan bersifat deskriptif. Menurut (Cresswell, 2017) penelitian kualitatif merupakan penelitian yang menggunakan 
latar alamiah, dengan maksud menafsirkan fenomena yang terjadi dan dilakukan dengan jalan melibatkan berbagai metode yang ada (Satori \& Komariah, 2009).

Pendekatan kualitatif adalah pendekatan yang penting untuk memahami suatu fenomena sosial dan perspektif individu yang diteliti. Pendekatan kualitatif juga merupakan yang mana prosedur penelitiannya menghasilkan data deskriptif yang berupa kata-kata yang secara tertulis ataupun lisan dari prilaku orang-orang yang diamati (Wahyuni, 2013).

Dalam penelitian ini menggunakan jenis penelitian case study research (studi kasus). Menurut Suharsimi Arikunto studi kasus adalah pendekatan yang dilakukan secara intensif, terperinci dan mendalam terhadap gejala-gejala tertentu (Wahyuni, 2013).

Design yang digunakan adalah single case design yaitu suatu penelitian studi kasus yang menekankan penelitian hanya pada sebuah unit kasus aja. Jadi peneliti berfokus pada satu objek tertentu yang mempelajarinya sebagai suatu kasus. Data studi kasus dapat diperoleh dari semua pihak yang bersangkutan, dengan kata lain dalam studi ini dikumpulkan dari beberapa sumber. Tujuan penelitian yang utama tidak terletak pada generalisasi hasil, melainkan keberhasilan suatu treatment pada suatu waktu tertentu. Keuntungan menggunakan desain penelitian ini adalah dapat digunakannya perubahan ditengah penelitian atau intervensi terhadap konseli.

Penelitian ini menggunakan tipe penelitian studi kasus instrumental. Studi kasus instrumental adalah suatu kasus unik tertentu dilakukan untuk memahami isu dengan lebih baik juga untuk mengembangkan, memperhalus teori. Penelitian studi kasus merupakan penelitian yang digunakan untuk memperoleh pemahaman utuh dan terintregasi mengenai inter-realas berbagai fakta dan dimensi dari suatu kasus khusus. Kasus sendiri didefinisikan sebagai fenomena khusus yang hadir dalam suatu konteks yang terbatasi, meski batas-batas antara fenomena dan konteks tidak sepenuhnya jelas (Poerwandari, 2007).

Penelitian studi kasus dipilih karena peneliti ingin memahami fenomena secara spesifik dan mendalam, termasuk individu-individu, kelompok, situasi unik yang berkaitan dengan fenomena yang diteliti.

Dalam pendekatan kasus ini akan diteliti putusan yang terkait langsung dengan objek penelitian, yang merupakan objek sasaran kasus yang diangkat oleh penulis, yaitu Putusan Pengadilan Tinggi Bandung Nomor 476/Pdt/2020/Pt. Bdg Tanggal 30 September 2020 jucto Putusan Pengadilan Negeri Depok Nomor 229/Pdt.Plw/2019/PN. Dpk. Tanggal 13 Mei 2020.

2. Pendekatan Konseptual (Conseptual Approach).

Pendekatan ini beranjak dari pandangan-pandangan dan doktrin-doktrin yang berkembang di dalam ilmu hukum. Pendekatan ini menjadi penting sebab pemahaman terhadap pandangan/doktrin yang berkembang dalam ilmu hukum dapat menjadi pijakan untuk membangun argumentasi hukum ketika menyelesaikan isu hukum yang dihadapi. Pandangan atau doktrin-doktrin dapat memperjelas ide-ide 
dengan memberikan pengertian-pengertian hukum, konsep hukum maupun asas hukum yang relevan dengan permasalahan (Marzuki, 2010).

3. Pendekatan Perundang-Undangan (Statue Approach).

Pendekatan perundang-undangan adalah penulisan yang dilakukan dengan menelaah semua undang-undang dan regulasi yang bersangkut-paut dengan isu hukum yang sedang ditangani. Dalam pendekatan perundang-undangan ini akan diteliti perundang-undangan yang terkait dengan objek jaminan fidusia yang disita oleh Negara ditinjau dari konsep Undang-Undang Nomor 42 Tahun 1999 Tentang Jaminan Fidusia (UUJF).

\section{Hasil dan Pembahasan}

\section{A. Hasil Penelitian}

Sekalipun dalam UUJF sendiri tidak ada ketentuan pasal yang mengatur mengenai objek jaminan fidusia yang digunakan untuk melakukan tindak kejahatan dan dirampas negara, namun pada prakteknya di lapangan, apabila terjadi perampasan objek jaminan fidusia, akibat yang ditimbulkan adalah kerugian bagi kreditur sebagai pemegang jaminan fidusia, karena objek jaminan yang menjadi jaminan utang dari debitur selaku pemberi fidusia dirampas oleh negara melalui putusan pengadilan yang telah memiliki kekuatan hukum tetap (incracht van recht) yang menyebabkan objek fidusia tersebut tidak dapat dieksekusi ketika debitur tidak dapat melakukan pelunasan terhadap utang-utangnya.

Adapun kasus yang diangkat dan akan dibahas oleh peneliti saat ini adalah kasus terhadap perkara Perlawanan Nomor: 229/Pdt.Plw/2019/PN.DPK di Pengadilan Negeri Depok, yang telah dikeluarkan putusannya oleh Majelis Hakim Pengadilan Negeri Depok pada tanggal 13 Mei 2020 dan selanjutnya telah dimohonkan Banding ke Pengadilan Tinggi Bandung dengan Nomor Perkara: 476/PDT/2020/PT.BDG yang telah pula dikeluarkan putusannya oleh Majelis Hakim Pengadilan Tinggi Bandung pada tanggal 30 September 2020, dan yang saat ini tengah dalam proses Peninjauan Kembali di Mahkamah Agung Republik Indonesia.

\section{B. Pembahasan}

\section{Duduk Perkara dan Kasus Posisi Dalam Gugatan Perlawanan}

a. Bahwa PT Mizuho Balimor Finance (selanjutnya disebut PELAWAN) merupakan suatu Badan Hukum yang berkedudukan dan berkantor pusat di Jakarta, yang melakukan usaha dalam bidang Pembiayaan dan didirikan berdasarkan ketentuan hukum serta peraturan perundang-undangan yang berlaku di Indonesia sebagaimana dimaksud dalam Undang-Undang No. 40 Tahun 2007 Tentang Perseroan Terbatas, serta telah berkontribusi dalam menjalankan roda perekonomian di Negara Republik Indonesia;

b. Bahwa PELAWAN merupakan Kreditur atas fasilitas pembiayaan kendaraan bermotor yang telah diberikan oleh PELAWAN kepada TURUT 
TERLAWAN 1, melalui Perjanjian Pembiayaan Konsumen dengan objek fasilitas pembiayaan berupa 1 (satu) Unit Mobil Honda Mobilio RS CVT;

c. Bahwa didasarkan pada Perjanjian Pembiayaan, TURUT TERLAWAN 1 berkewajiban membayar angsuran kepada PELAWAN dengan meliputi pokok hutang dan bunga serta denda yang timbul bilamana TURUT TERLAWAN 1 mengalami keterlambatan dalam pembayaran angsuran; Dll.

\section{Hal Yang Dimintakan Oleh Pelawan Kepada Majelis Hakim Dalam} Petitum Perlawanan

Berdasarkan segala apa yang terurai diatas, maka selanjutnya Pelawan meminta kepada Pengadilan Negeri di Depok agar berkenan memutuskan:

\section{DALAM PROVISI (Terlebih Dahulu):}

a) Menerima dan Mengabulkan permohonan Provisionil yang dimohonkan PELAWAN dalam Perkara ini;

b) Memerintahkan kepada TERLAWAN untuk menunda pelaksanaan eksekusi Pelelangan Kendaraan dan segera menyerahkan Kendaraan berupa: 1 (satu) Unit Mobil Mobilio tanpa STNK warna Putih Nopol B 154 NCA kepada PELAWAN agar dapat dijaga dan dirawat oleh PELAWAN, sampai dengan putusan dalam perkara ini mempunyai kekuatan hukum yang tetap dan pasti (in kracht van gewijsde).

\section{DALAM POKOK PERKARA:}

\section{PRIMAIR:}

a) Menerima Perlawanan (derden verzet) PELAWAN untuk seluruhnya;

b) Menyatakan PELAWAN sebagai PELAWAN yang baik dan benar (allgoed opposant);

c) Menyatakan penetapan atas perampasan barang bukti untuk dilelang dan hasilnya akan dimasukkan dalam kas negara sebagaimana Amar Putusan Pengadilan Negeri Depok dalam Perkara Pidana No.: 429/Pid.Sus/2017/PN.Dpk khususnya pada Bagian Nomor 5 Point ke-8 yaitu : 1 (satu) Unit Mobil Mobilio tanpa STNK warna Putih Nopol B 154 NAC adalah batal dan tidak memiliki kekuatan hukum;

d) Memperbaiki Amar Putusan Pengadilan Negeri Depok dalam Perkara Pidana No.: 429/Pid.Sus/2017/PN.Dpk khususnya pada Bagian Nomor 5 Point ke-8 yaitu: 1 (satu) Unit Mobil Mobilio tanpa STNK warna Putih Nopol B 154 NCA menjadi dikembalikan kepada PELAWAN;

e) Memerintahkan kepada TERLAWAN untuk mengembalikan barang (Kendaraan) milik PELAWAN berupa: 1 (satu) Unit Mobil Mobilio tanpa STNK warna Putih Nopol: B 154 NCA dalam waktu 1 (satu) minggu setelah dibacakannya Putusan ini kepada PELAWAN;

f) Menyatakan bahwa Putusan ini dapat dilaksanakan terlebih dahulu (uitvoerbaar bijvoorraad), walaupun ada upaya hukum banding atau kasasi;

g) Menghukum TURUT TERLAWAN 1 dan TURUT TERLAWAN 2 untuk tunduk dan patuh terhadap Putusan perkara ini; 
h) Menghukum TERLAWAN untuk membayar biaya perkara ini.

\section{SUBSIDAIR:}

Apabila Majelis Hakim yang memeriksa perkara ini berpendapat lain, mohon putusan yang adil dan layak (ex aquo et bono).

\section{1) Putusan Pengadilan Negeri Depok}

Dalam pertimbangan-pertimbangannya Majelis Hakim Pengadilan Negeri Depok berpendirian bahwa:

a. Bahwa Pelawan adalah pihak ketiga yang mempunyai kuasa hak menarik obyek jaminan yang sah serta beralasan menurut hukum untuk melakukan eksekusi dengan itikad baik untuk mempertahankan haknya atas pelunasan hutang Turut Terlawan I kepada Pelawan;

b. Bahwa Oleh karena Pelawan adalah pihak ketiga yang mempunyai kuasa hak menarik obyek jaminan guna pelunasan piutangnya maka berdasarkan Pasal 46 ayat 1 jo Pasal 194 KUHAP jo Pasal 195 ayat (6) HIR Pelawan harus dinyatakan baik dan benar;

c. Bahwa mengenai pendapat Terlawan yang pada pokoknya menyatakan bahwa hak Pelawan dengan jaminan fidusia atas barang bukti tersebut hilang atau berpindah ke Negara karena ada amar putusan. Pidana yang sudah berkekuatan hukum tetap menyatakan supaya dirampas untuk Negara maka haruslah dikesampingkan dikarenakan sebagaimana pertimbangan hukum sebelumnya bahwa telah dapat dibuktikan bahwa Pelawan dapat dikategorikan sebagai Pelawan yang beritikad baik yang harus mendapat perlindungan hukum sebagaimana ditentukan dalam Pasal 20 jo Pasal 24 UU Nomor 42 Tahun 1999

d. Bahwa Pelawan telah berhasil membuktikan dalil- dalilnya perlawanannya mengenai hak pelawan terhadap benda obyek sengketa sedangkan Terlawan tidak berhasil membuktikan dalil-dalil sangkalannya; Dll.

\section{2) Penyelesaian Perkara Pada Tingkat Banding}

Bahwa selanjutnya, Pembanding dahulu Terlawan mengajukan permohonan Banding kepada Majelis Hakim Pengadilan Tinggi Jawa Barat agar Majelis hakim berkenan memberikan putusan Membatalkan Putusan Pengadilan Negeri Depok No: 229/Pdt.Plw/2019/PN.Dpk tanggal 13 Mei 2020, dan atas memori banding tersebut selanjutnya Kuasa Hukum Terbanding semula Pelawan telah mengajukan Kontra Memori Banding tertanggal 19 Juni 2020, dan meminta serta mohon kepada Majelis Hakim Pengadilan Tinggi Jawa Barat di Bandung yang memeriksa dan mengadili perkara ini untuk mengesampingkan Memori Banding dari Pembanding/dahulu Terlawan dan selanjutnya memutuskan untuk menolak permohonan banding dari Pembanding/dahulu Terlawan serta menguatkan Putusan Pengadilan Negeri Depok Nomor: 229/Pdt.Plw/2019/PN.Dpk tertanggal 13 Mei 2020; 


\section{3) Putusan Pengadilan Tinggi Bandung}

Dalam pertimbangan-pertimbangannya Judex Factie Pengadilan Tinggi Bandung berpendirian:

a. Bahwa Majelis Hakim tingkat banding dapat menyetujui dan membenarkan putusan Majelis Hakim tingkat pertama tersebut, karena pertimbangan-pertimbangan hukumnya telah memuat dan menguraikan dengan tepat dan benar semua keadaan serta alasan-alasan yang mejadi dasar dalam putusannya dan pertimbangan Putusan Majelis Hakim Tingkat Pertama baik putusan dalam Eksepsi, provisi maupun dalam pokok perkara seluruhya dijadikan sebagai pertimbangan Majelis Hakim tingkat banding sendiri dalam memutus perkara ini dalam tingkat banding;

b. Bahwa oleh karena pertimbangan-pertimbangan hukum Majelis Hakim tingkat pertama tersebut diambil alih dan dijadikan dasar pertimbanganpertimbangan putusan Majelis Hakim tingkat banding sendiri, maka putusan Pengadilan Negeri Depok Nomor 229/Pdt.Plw/2019/PN.Dpk tanggal 13 Mei 2020 dapat dipertahankan dan dikuatkan dalam peradilan Tingkat Banding.

c. Selanjutnya dengan mengingat undang-undang yang berlaku terutama UU No. 42 Tahun 1999, Undang-Undang RI Nomor: 20 Tahun 1947 tentang Banding dan Peraturan Perundang Undangan lain yang terkait.

\section{Kesimpulan}

Jaminan fidusia mengikuti objeknya dalam tangan siapapun objek jaminan fidusia tersebut berada (Pasal 20 UUJF No. 42 Tahun 1999). Sifat ini dikenal dengan istilah droit de suit yang merupakan salah satu hak khusus bagi kepentingan kreditur pemegang sertifikat jaminan fidusia. Walaupun objek jaminan fidusia sudah berpindah tangan dan dikuasai oleh pihak lain, kreditur masih tetap dapat menggunakan haknya melalui eksekusi jika debitur cidera janji. Jaminan fidusia juga tidak akan berakhir sekalipun objek jaminan fidusia itu telah berpindah tangan kepada pihak lain oleh sebab apapun, termasuk dalam kasus yang diangkat dan dibahas oleh penulis pada penelitian ini. Dengan demikian status kepemilikan objek jaminan fidusia yang telah dinyatakannya "dirampas oleh negara" berdasarkan suatu putusan pengadilan tidak akan hilang dan tetap melekat pada pemegang sertifikat jaminan fidusia tersebut. Hal yang sama juga menjadi bahan pertimbangan utama bagi Majelis Hakim Tingkat Pertama dalam Putusannya Nomor: 229/Pdt.Plw/2019/PN.Dpk Tanggal 13 Mei 2020, yang salah satu dalil pertimbangannya berbunyi: Bahwa Pelawan adalah pihak ketiga yang mempunyai kuasa hak menarik obyek jaminan yang sah serta beralasan menurut hukum untuk melakukan eksekusi dengan itikad baik untuk mempertahankan haknya atas pelunasan hutang Turut Terlawan I kepada Pelawan. Putusan mana diperkuat lagi oleh Majelis Hakim Tingkat Banding berdasarkan Putusan Pengadilan Tinggi Bandung Nomor: 476/PDT/2020/PT.BDG Tanggal 30 September 2020. Dengan 
kata lain, Pelawan selaku Kreditur sekaligus Penerima Fidusia, mempunyai "kuasa hak" menarik obyek jaminan yang sah serta beralasan menurut hukum untuk melakukan eksekusi terhadap obyek jaminan fidusia tersebut, sehingga oleh karenanya Pelawan dinyatakan sebagai Pelawan yang beritikad baik dan sah selaku pemilik serta pemegang jaminan fidusia atas 1 (satu) Unit Mobil Merk dan Model: Honda Mobilio RS CVT, Tahun/Warna 2015/ Putih Metalik, Nomor Polisi: B 154 NCA, No. Rangka/Mesin: MHRDD4870FJ458418/L15Z11211115 yang dilindungi berdasarkan undang-undang.

Kepastian hukum atas suatu kepemilikan objek jaminan fidusia yang telah dinyatakan dirampas oleh negara berdasarkan putusan pengadilan sudah dapat dibuktikan melalui putusan Pengadilan Tinggi Bandung Nomor: 476/PDT/2020/PT.BDG Tanggal 30 September 2020 juncto putusan Pengadilan Negeri Depok Nomor: 229/Pdt.Plw/2019/PN.Dpk Tanggal 13 Mei 2020, meskipun kenyataannya dilapangan kepastian hukum terhadap hal ini masih belum dapat dijamin keseragamannya secara utuh dikalangan penegak hukum. Masih munculnya berbagai macam gugatan di masyarakat umum di Indonesia dalam rangka mempertahankan hakhak kepemilikan kreditur terhadap objek jaminan, khususnya objek jaminan fidusia, semakin menggambarkan bahwa sampai saat ini tujuan hukum dari sistem hukum yang ada di Indonesia, yaitu adalah kepastian hukum, belum dapat terwujud sempurna. Hal ini selaras dengan karakteristik dari sistem hukum Eropa Kontinental yang berlaku di Indonesia, yang salah satunya yaitu: "putusan hakim tidak mengikat umum tetapi hanya mengikat para pihak yang berpekara saja". Hak tersebut banyak menimbulkan celah kepastian hukum di kalangan penegak hukum khususnya dilingkungan peradilan di Indonesia. Penelitian ini dapat dijadikan sebagai salah satu contoh adanya ketidakseragaman suatu kepastian hukum atas putusan pengadilan tentang perlawanan dari pihak ketiga yang dirugikan (khususnya kreditur) dalam hal objek jaminan fidusianya disita dan dirampas oleh negara untuk kepentingan umum. Padahal jika mengacu pada Pasal 5 Undang-Undang Republik Indonesia Nomor 12 Tahun 2011 Tentang Pembentukan Peraturan Perundang-Undangan, bahwa mengenai Asas Pembentukan Peraturan Perundang-undangan diatur sebagai berikut:

“... Dalam membentuk Peraturan Perundang-undangan harus dilakukan berdasarkan pada asas Pembentukan Peraturan Perundang-undangan yang baik, yang meliputi:

\section{a. kejelasan tujuan;}

b. ...dst..."

Yang mana di dalam Penjelasannya disebutkan bahwa yang dimaksud dengan "asas kejelasan tujuan" adalah bahwa setiap pembentukan peraturan perundang-undangan harus mempunyai tujuan yang jelas yang hendak dicapai. Dan jika kita memperhatikan kembali salah satu tujuan daripada dibentuknya Undang-Undang No. 42 Tahun 1999 Tentang Jaminan Fidusia, maka sudah jelas dinyatakan dalam butir pertimbangannya yaitu:

“...c. Bahwa untuk memenuhi kebutuhan hukum yang dapat lebih memacu pembangunan nasional dan untuk menjamin kepastian hukum serta mampu 
memberikan perlindungan hukum bagi pihak yang berkepentingan, maka perlu dibentuk ketentuan yang lengkap mengenai Jaminan Fidusia dan jaminan tersebut perlu didaftarkan pada Kantor Pendaftaran Fidusia..."

Dengan demikian meskipun dalam kasus yang dijadikan oleh penulis sebagai alat penelitian tesis ini telah dapat membuktikan adanya kepastian hukum atas kepemilikan objek jaminan fidusia yang telah dinyatakan dirampas oleh negara, berdasarkan putusan Pengadilan Tinggi Bandung Nomor: 476/PDT/2020/PT.BDG Tanggal 30 September 2020 juncto putusan Pengadilan Negeri Depok Nomor: 229/Pdt.Plw/2019/PN.Dpk Tanggal 13 Mei 2020, namun sayangnya sampai dengan saat ini, masih banyak gugatan di masyarakat umum di Indonesia, khususnya yang berasal dari pihak-pihak yang dirugikan, yang dalam rangka mempertahankan hak-hak kepemilikan kreditur terhadap objek jaminan, khususnya objek jaminan fidusia, sehingga kepastian hukum UndangUndang No. 42 Tahun 1999 Tentang Jaminan Fidusia, belum dapat terwujud secara sempurna. Adapun kendala-kendala yang ditemui dilapangan ketika upaya hukum diajukan oleh pihak ketiga terhadap putusan perampasan barang dalam suatu perkara pidana, semata-mata dikarenakan belum adanya keseragaman administrasi dan payung hukum yang khusus mengatur mengenai upaya hukum pihak ketiga terhadap putusan perampasan barang dalam perkara pidana. 


\section{BIBLIOGRAFI}

Cresswell, J. W. (2017). Research Design: Pendekatan Kualitatif, Kuantitatif, dan Mixed (Edisi Ketiga). Yogyakarta: Pustaka Belajar. Google Scholar

Darmaji, Muhammad. (2006). Jaminan-jaminan Dalam Pemberian Kredit Menurut Hukum Indonesia. Jakarta: Pradnya Paramitha.

Darwanto, Faisal. (2006). Sekilas Tentang Perjanjian Sewa Beli Sebagai Perjanjian Tak Bernama. Jakarta: Rajawali Press. Google Scholar

Djasman, Muktar. (2009). Perusahaan Pembiayaan dan Perjanjian Sewa Beli. Surabaya: Mitra Ilmu Surabaya. Google Scholar

Elfanto Jurdana. (2007). Lembaga Pembiayaan Dalam Teori dan Praktek. Jakarta: Ghalia Indonesia.

Gunawan Widjaja \& Ahmad Yani. (2000). Jaminan Fidusia. Jakarta: Raja Grafindo Persada. Google Scholar

Jenie, Siti Ismijati. (1996). Beberapa Perjanjian Yang Berkenaan Dengan Kegiatan Pembiayaan. Bahan Penataran Dosen Hukum Perdata, Fakultas Hukum UGM, Yogyakarta. Google Scholar

Marzuki, Peter Mahmud. (2010). Penulisan Hukum, Edisi Revisi. Jakarta: Kencana Prenada Media Group. Google Scholar

Poerwandari, E. Kristi. (2007). Pendekatan kualitatif untuk penelitian perilaku manusia. LPSP3 Fakultas Psikologi Universitas Indonesia. Google Scholar

Purnamasari, Irma Devita. (2012). Kiat-Kiat Cerdas, Mudah, dan Bijak Memahami Masalah Hukum Waris. Google Scholar

R. Supomo. (2005). Hukum Acara Pidana Pengadilan Negeri. Jakarta: Pradnya Paramita Jakarta.

Satori, Djam'an, \& Komariah, Aan. (2009). Metodologi penelitian kualitatif. Bandung: Alfabeta, 22. Google Scholar

Sulistiyono, Adi, \& Rustamaji, Muhammad. (2009). Hukum Ekonomi Sebagai Panglima. Budiarjo: Masmedia Buana Pustaka. Google Scholar

Wahyuni. (2013). Pengembangan Koleksi Jurnal studi Kasus di perpustakaan. Yogjakarta: UIN Sunan Kalijaga. Google Scholar

\section{Copyright holder:}

Aneta Indriya Sari, Gunawan Djajaputra (2021) 
Kepastian Hukum Atas Suatunkepemilikan Objek Jaminan Fidusia Yang Telah

Dinyatakan Dirampas Oleh Negara Berdasarkan Putusan Pengadilan

First publication right:

Syntax Literate: Jurnal Ilmiah Indonesia

This article is licensed under:

(c) (7) (?) 